\title{
Human resource management and performance at the Indian railway
}

Article

Accepted Version

Pereira, V., Fontinha, R., Pawan, B. and Arora, B. (2018)

Human resource management and performance at the Indian railway. Journal of Organizational Change Management, 31 (1). pp. 47-61. ISSN 0953-4814 doi:

https://doi.org/10.1108/JOCM-04-2017-0157 Available at https://centaur.reading.ac.uk/71884/

It is advisable to refer to the publisher's version if you intend to cite from the work. See Guidance on citing.

To link to this article DOI: http://dx.doi.org/10.1108/JOCM-04-2017-0157

Publisher: Emerald Group Publishing Limited

All outputs in CentAUR are protected by Intellectual Property Rights law, including copyright law. Copyright and IPR is retained by the creators or other copyright holders. Terms and conditions for use of this material are defined in the End User Agreement.

\section{www.reading.ac.uk/centaur}

\section{CentAUR}

Central Archive at the University of Reading 
Reading's research outputs online 


\section{Human Resource Management and Performance at the Indian Railways.}

\begin{tabular}{|r|l|}
\hline Journal: & Journal of Organizational Change Management \\
\hline Manuscript ID & JOCM-04-2017-0157.R1 \\
\hline Manuscript Type: & Research Paper \\
\hline Keywords: & $\begin{array}{l}\text { High performance work practices, Multiple stakeholders, Multiple } \\
\text { performance indicators, Public Sector, Indian Railways }\end{array}$ \\
\hline \multicolumn{2}{|l}{} \\
\hline
\end{tabular}

\section{SCHOLARONE ${ }^{\text {M }}$ \\ Manuscripts}


Human Resource Management and Performance at the Indian Railways. 


\section{Abstract}

Purpose: High-performance-work-practices (HPWP) have been well documented within private organisations in developed country economies. Such practices, however, remain under-investigated in the public sector and in emerging economies. This paper aims to work towards filling this void, by empirically evaluating HPWP within an Indian public-sectorundertaking (PSU), also the world's largest commercial public sector employer: The Indian Railways.

Design/methodology/approach: We investigate whether the practices implemented in this organisation are consistent with the idea of HPWP, and analyse how they are influenced by different stakeholders and ultimately associated with different indicators of organisational performance. We focused on six railway zones and interviewed a total of $62 \mathrm{HR}$ practitioners. Findings: Our results show that most practices implemented are aligned with the idea of HPWP, despite the existence of context-specific unique practices. Furthermore, we identify the influence of multiple stakeholders in decision making concerning different practices. We additionally found that the measurement of performance goes beyond financial indicators and several context-specific non-financial indicators are identified and their social importance is reiterated.

Originality/value: Theoretically, this paper utilises and contributes to the resource-based view of firms by identifying a distinctive bundle of competencies in human resources through HPWS in the Indian Railways.

Key Words: High performance work practices; Multiple stakeholders; Multiple performance indicators; Public Sector; Indian Railways 


\section{Introduction}

The Indian Railways, the world's largest commercial public sector enterprise, has been researched for different aspects relating to business and management, such as its management style, human resource management, culture, employment relations etc., in the recent past (e.g. Pereira, 2014; Pereira and Fontinha, 2015; Pereira and Malik, 2015; Pereira and Malik, 2017; Pereira and Narayanamurthy, 2016). This paper contributes to this body of knowledge by identifying the multiple stakeholders and links high performance work practices (HPWP) to different indicators of performance in the Indian Railways.

There have been several attempts to explain the relationship between human resource practices and firm performance (e.g., Legge, 1995; Boxall \& Purcell; 2003). In this context Almond (2011:260) argues that when it comes to the 'relational perspective' between the buyers and sellers of labour, certain "normative HRM theories such as the notion of 'High Performance Work Systems' can be seen as an attempt to institutionalise a set of ideas about what is the 'right' way to manage the effort-reward bargain within paid employment". As a consequence, the construct of High Performance Work Practices (HPWP) is now rather well established, especially with reference to developed country economies (e.g., Bae et al, 2011).

However, research in HPWP remains predominantly led by North American thinking and secondarily by thinking from economically developed nations. There is no guarantee that concepts and management practices that have been developed and tested in "western" economies apply in emerging economies or in economies embedded in societies with different cultural characteristics, such as Asian societies (Lynn, 2006; Tung, 2006). To take the case of India, which represents a major emerging economy, though awareness of strategic human resource management and relevant practices may exist in nascent form in India (Budhwar \& Varma, 2010; Som, 2008), to date the extent to which human resource practices fit within the framework of HPWP in the country remains unaddressed. 
Analysing transitional economies is crucial to build theory and understand the dynamics at the boundary between institutions and organizations (Chiaburu, 2006). This theory-building is extremely relevant when focusing on HRM Systems, as they are particularly influenced by the local context. HRM research has been dominated by survey methodologies that attempted to identify what practices constitute HPWS and statistical links between HPWP and organizational performance. Important issues that still remain, however, include why HPWP are adopted in the first place, decisions behind their adoption, and the role of different stakeholders in these decisions and implementation of HPWP's (Glover and Butler, 2012). Little is also known 'about the processes by which these plans and policies come to be implemented' (Hutchinson, Purcell and Kinnie, 2000:63). Such questions remain unanswered, with an ongoing call for qualitative in-depth case-studies (e.g. Guest, 2011), particularly when focusing on relatively under-explored contexts, such as emerging markets.

Additionally, most 'HRM-firm performance' research in emerging economies looks at the private sector, with the public sector being ignored. The public sector provides a particularly distinctive context as decision making is likely to be influenced by the demands of different stakeholder groups, such as central government, citizens, service users, local politicians (Perry and Porter, 1982; Rainey, 2009), as well as more traditionally involved groups such as trade unions, employees and managers. The public sector context is also distinctive in terms of its measures of performance: although there is a concern with productivity and profitability, public sector organisations also need to provide citizens and service users with efficient and effective services (Decramer, Smolders, and Vanderstraeten, 2013). This efficiency is crucial for local communities and is likely to be measurable by nonfinancial indicators.

Our research was motivated by these gaps. A high performing case-study Indian PSU organization, the Indian Railways, was chosen. The Indian Railways (IR) represents the 
world's largest commercial employer and one of the largest public sector organizations globally. First, conducting research in India, which represents a major emerging economy, is in line with the increasing need for evaluation and testing of predominantly "western" theories and models in non-western contexts that will enable to develop theories that apply specifically into these contexts. Second, we used a qualitative methodological approach interviewing 62 members of Indian Railway's senior management, human resource managers and HR employees in order to explore: a) who are the main stakeholders influencing HR decision making; b) what are the HR practices they implement and the extent to which these practices match the HPWPs identified in the literature; c) what are the main financial and non-financial indicators used in defining performance in this large PSU. We further back up these performance indicators with data from the Indian Railway's Annual Statistical Statements published by the Railway Board - Ministry of Railways - Government of India.

\section{Theoretical Background and Research Questions}

The idea for a link between human resource practices and firm performance has been in existence for some time (e.g., Arthur, 1994; Pfeffer, 1994; 1995; Paauwe, 2004). Authors have argued that well thought long-term oriented, coherent HR practices that cover all core human resource areas can significantly improve the workforce's ability, motivation and opportunity to behave in ways that are consistent with the firm's goals and, hence, advance bottom line firm outcomes (Appelbaum, Bailey, Berg and Kalleberg, 2000; Becker, Huselid, Pinckus and Spratt, 1997; Budhwar, Luthar and Bhatnagar, 2006). A number of labels have been utilized to connote these performance enhancing human resource practices (see Posthuma, Campion, Masimova and Campion, 2013), the term adopted in the present work being "High Performance Work Practices" (HPWP) that was introduced in the seminal work of Huselid (1995). Empirical evidence generally provides support to this assumption, finding links between HPWP and indices of organizational performance (e.g., Collins \& Smith, 2006; 
Huselid, 1995; Sun, Aryee and Law, 2007; Wright, Gardner and Moynihan, 2003). However, there has been inconsistency over the exact nature of systems and practices that compose HPWP (see, for example, Boselie, Dietz and Boon, 2005; Patel, Messersmith and Lepak, 2013; Sun et al., 2007). Our first research question explores a unique bundle in the context of the Indian Railways.

Of the several variants of the 'high-performance' paradigm, three seem to stand out due to its increased and interchangeable usage in empirical investigation (e.g., Pfeffer, 1998; Guest, 2011). These were the high management strategies of commitment (HCM), involvement (HIM) and performance (HPWS). This paper thus aims to distinguish and the unique bundle of HR practices that include these three variants or concepts i.e. HCM, HIM and HPWS's. High commitment management (HCM) (Walton, 1985; Wood 1999a, 1999b; Wood and Albanese, 1995) and "high involvement management (Lawler, 1986; Pil and MacDuffie, 1996) are widely used variant of the 'high performance' paradigm. The fundamental premise of these alternative terms suggests that there are identified practices that affect organizational commitment and involvement, which in turn, are assumed to influence organizational performance.

Whether HPWP are universally or contingently relevant has been a major issue in the literature (e.g. Becker and Gerhart, 1996). On the one hand, it has been argued that certain HR practices which if adapted will universally result in superior performance whatever the context and bring benefits (universalist view). On the other hand, others argue that these practices need to be fitted to the organization and its overall strategies (contingent view). The literature is rife with such arguments and its better known as 'best practice' and 'best fit' respectively (Purcell, 2006). The present work also looked at this issue, by investigating whether the work practices in the case organization fully fit into our chosen HPWP 
framework, a fact that would support the universalistic, 'best fit', approach, or show deviation from that framework, which would lend more support to the contingency, 'best fit' view.

Because these HPWS theories and models have been predominantly tested and evaluated in a Western context in private sector organisations, and this being the centre of a large number of previous research on HPWS, it was felt that the two concepts namely the 'universalist' (best practice) and 'contingency' (best fit) models needed to be tested in an emerging market context, specifically in the public sector.

These context specificities (i.e., being a public sector undertaking of large dimensions in an emerging market) are also likely to influence the way in which HPWS are designed, particularly because decision making tends to involve multiple stakeholders. Public sector organisations are under the scrutiny of different individuals and groups inside and outside the organisation. Due to their relevant societal role, public sector organisations include multiple stakeholders involved in decision making, specifically decision making concerning the characteristics of HPWS. Besides being influenced by managers, employees and trade unions, HPWS in public sector organisations are likely to be influenced by different stakeholder groups, such as central government, citizens, service users, and local politicians (Perry and Porter, 1982; Rainey, 2009). We now aim to investigate who the different stakeholders are influencing decision making regarding HPWS in the Indian Railways and their role in shaping different practices.

Furthermore, we focus on the way performance is measured in the Indian Railways. According to Lebans and Euske (2006, p.71) organisational performance is defined as a "set of financial and non-financial indicators, which offer information on the degree of achievement of objectives and results". This is inspired by Kaplan and Norton's (1996) model of firm performance on the basis of the Balance Scorecard, which differentiated 
between financial and non-financial measurement of performance. They identified return on assets, working capital, return on investment and return on equity as non-financial indicators, and financial perspective, customer orientation perspective, organisational effectiveness, and learning growth and perspective, as non-financial indicators (Kaplan and Norton, 1996). The public sector context is one where performance is likely to be evaluated considering both types of performance indicators, since there is a concern profitability, but also a need to provide citizens and service users with efficient and effective services (Decramer et al., 2013). The Indian Railways is a commercial PSU, which means that there is a clear concern with its financial performance indicators, but at the same time it is an organisation with a major social impact in India, with a crucial role in the transport of goods and people. Thus, it is our aim to investigate what are the main financial and non-financial indicators of performance in this large PSU.

Based on the above theoretical background, we investigate two research questions: Research question 1: What are the unique HRM practices that collectively as a bundle form unique HPWP/S's in the Indian Railways, how are they implemented, and who are the main stakeholders influencing them?

Research question 2: What are the main financial and non-financial indicators used in defining performance in the Indian Railways?

\section{Method}

This empirical study was conducted in 2009-2010 in the Indian Railways and was sponsored by a research grant from the Society for Human Resource Management (SHRM; United States). Indian Railways (IR) has a state monopoly on India's rail transport (Ministry of Railways) and is the world's largest commercial or utility employer, with approximately 1.7 million employees. IR is one of the largest and busiest rail networks in the world, 
transporting 18 million passengers and more than two million tonnes of freight daily (IR budget reports, 2012-13). The Railway Board, which is the organization that manages the Indian Railways, gave permission and access to conduct the study. Indian Railways comprises 16 geographic zones covering all India, subdivided into 67 divisions. Given the dimension of this organization, it was decided to conduct the study in six zones that would represent different geographical areas of India, namely Western Railways, Central Railways, North-Eastern Railways, North-Central Railways, South-Western Railways, and SouthCentral Railways. These regions include 30 of the 67 divisions in Indian Railways. This study relied on sources of both primary and secondary data. Primary empirical data were collected by conducting 62 semi-structured interviews with top level HR managers and line managers responsible for HR. These interviews were conducted with the objective of obtaining a detailed description of current work and HR practices, the involvement of different stakeholders in designing these practices, how they are being implemented and how they are articulated creating a HR system. Content analysis was used to interpret qualitative interview data. Secondary data from the Indian Railway's Annual Statistical Statement (2010-11), produced by the Ministry of Railways - Government of India, was used to investigate objective financial indicators like the cost of staff and gross total expenditure and non-financial indicators like absenteeism due to sickness and labour trouble, the number of attacks and deaths under various kinds of diseases on the Railway Offices, the number of train accidents, casualties and injuries.

\section{Results}

The qualitative data retrieved from the interviews has allowed us to reply to our research questions. Figure 1 helps to visually summarize these results. 
Our first research question was "What are the unique HRM practices that

collectively as a bundle form unique HPWP/S's in the Indian Railways and who are the main stakeholders influencing them?". Qualitative data from the interviews allowed us to identify five main sets of HPWP (recruitment and selection; learning, training and development; compensation and benefits; employment relations; and employee welfare-oriented practices) and characterise the way they are being implemented in Indian Railways. These data also allowed us to identify who the main stakeholders influencing these practices are. These stakeholders will be highlighted using italics.

\section{Recruitment and Selection}

Recruitment and selection in the Indian railways is highly formalized and involves a number of different stakeholders. There are four categories of staff classified as classes I, II III and IV. Selection to class IV posts is conducted by railway administrations through Selection Boards. Employment Notices are issued locally and the assistance of the local Employment Exchange is sought to get the adequate number of suitable candidates. Class III posts are usually filled by Railway Service Commissions through open competition on an allIndia basis. Group A and B Officers (Class I \& II) are chosen through a competitive examination held by the Union Public Service Commission (UPSC - Civil services). For all the above posts a stringent medical examination is carried out by doctors in Indian Railways hospitals prior to final appointment. Interestingly, characteristics of HPWS can be identified:

'...there was an emphasis on the character and antecedents of potential employees these are also sought. Comprehensive training at the initial/induction stage is compulsory. Most positions have one-year probation, though this varies for departments and positions. Promotions from the lower grades are based on 'senioritycum-suitability' and in higher grades on 'merit only'. (Interview- Officer, Central Railway) 
Apart from the above recruitment and selection route, the Indian Railways are paternalistic in their outlook as they look after the family of staff even after their death, as is seen in the quote by an officer:

'A unique concept within the Indian Railways is the 'compassionate appointment' of a dependent child i.e. son / daughter or wife (above 18 years, subject to basic fulfilment of employment conditions), on the death of an employee. It was learnt that recently there have been calls from various political parties and people to employ regional or local candidates'. (Interview- Officer, Western Railway)

In addition, there is the assurance of a fixed career progression. Hence, though the remuneration is lower than in the private sector, railway employees enjoy "job security"" at all levels except under exceptional cases in an otherwise highly volatile job market. The low level of staff turnover is evident from the number of pensioners-a staggering 1 million, which equates to $\sim 1 \%$ and almost equal to the number of serving employees. It was also learnt that in the current economic climate there has been an increase in the number of applications for jobs in Indian Railways and is seen as a "job for life".

Indian Railways has witnessed dynamic changes in technology and modernisation, electrification, computerisation, mechanisation of track maintenance, etc. These are taking place at a fast pace, and to meet the challenges of its traffic requirements and changing environment, systematic manpower planning is seen to be essential. Indian Railways carries out a category-wise analysis of staff to identify surplus staff and to arrange manpower. This, as one officer puts it, "adjusts the surplus in one category to other categories, where there is demand" (Interview- Officer, South-Central Railway). Another officer said manpower planning "ensures that existing manpower is utilised to the maximum possible extent". It was also learnt that due to automation and modernisation, reduction in total employee strength has 
been approximately 1\% per annum” (Interview- Officer, Western Railway). Thus, according to an officer, "the total employee strength on the rolls has reduced from 1.7 million employees in 1999 to 1.4 million in 2009 and is projected to reduce to below 1.0 million by 2016” (Interview- Officer, North Central Railway).

\section{Learning, Training and Development}

Learning, Training and Development are available at all levels and is seen to be paramount to the Indian railways as it concerns transportation, and hence, safety. All new recruits undergo training when they join. Gazetted officers train at the following seven centralized training institutes (CTI): Railway Staff College, Vadodara; Indian Railways Institute of Civil Engineering, Pune; Indian Railways Institute of Signal Engineering \& Telecommunications, Secunderabad; Indian Railways Institute of Mechanical \& Electrical Engineering, Jamalpur; Indian Railways Institute of Electrical Engineering, Nasik; Indian Railways Institute of Transport Management, Lucknow; Jagjivan Ram Railway Protection Force Academy, Lucknow.

Gazetted officers also undergo management training courses both in India and abroad. In India these are held at the prestigious Indian Institute(s) of Management (IIM). Recently, Indian Railways signed a 5-year contract with HEC Paris, a global business school. HEC Paris will provide international learning programmes to middle and senior management and will become Indian Railways' biggest supplier of external learning for managers.

The training needs of non-gazetted staff are being taken care of by around 200 Indian Railways training centres. According to one officer:

'These training institutes and centres specialise in various functional training based on the different functions or departments. For example - for operating staff there is driver training, guard training, motorman training, etc. Apart from receiving training when 
they start out in their careers, railway personnel also receive periodic training in the form of refresher courses or when new methods or technology are introduced' (Interview- Officer, South-Western Railway).

An extensive training programme is planned and evaluated at the Indian Railways. An annual training calendar (January to December) is planned at the Board level, which is then percolated to the different zones and respective zonal training centres. This training calendar is rolled out every 5 years. The zonal training centres request for nominations from the divisions and schedule the training. Nominations are then sent from the divisions to the HQ and the zonal training centres for administration of training on the said date.

It was learnt that a few employees at all levels in the Indian Railways resist training outside their respective division / HQ, as they are required to stay away from their families over the duration of the training. Hence, employees prefer in-house training to outstation training at the zonal training centres. However, training attendance is compulsory for all technical 'running staff', i.e. staff associated with running of trains.

Post training, the training centres conduct examinations - both written and practical - to measure the effectiveness of training. Another method the railways use to measure effectiveness of a training programme is the use of simulation exercises - as is practiced in the Sabarmati locomotive maintenance section in Gujarat. The 'running' staff are expected to undergo a 'simulation' test where their abilities to run a train are tested. Here, in the words of an officer, "They will be allowed to operate the trains only if they pass the stringent simulation test" (Interview- Officer, Western Railway). The Sixth Pay Commission has also introduced training programmes such as 'Train the Trainer', wherein employees trained at the zonal training centres may train staff internally at the division. 


\section{Compensation and Benefits}

Pay and conditions at the Indian railways were complexly structured. The structure of emoluments and conditions of service of railway employees, like those of other Central Government employees, are reviewed periodically by the 'Pay Commissions' appointed by Government from time to time. Indian Railways' employees enjoy fringe benefits such as free passes and concessional tickets to travel the length and breadth of the country. These cover the employee and his / her dependent family at all levels. Many employees noted that these were factors that attracted them to join the railway service. Another 'motivational' or 'pull' factor to join the railways is the ability to maintain a "work-life balance" in comparison to the private sector. All employees from the regular establishment of the Railways are placed on time scales of pay, in which they draw annual increments as a matter of course, except on reaching an 'efficiency bar', which is consistent with performance-based pay in HPWS. Allowances are related to the cost of living index (as in the case of Dearness allowance). Employees are also compensated on account of unusual working hours or special nature of duties (such as night-duty allowance or running allowance), or inhospitable or expensive place of posting (such as bad climate allowance, hill allowance, house rent allowance, city compensatory allowance). The rules governing the pay and allowances, leave entitlement, retirement-cum-death benefits, etc., of railway employees are collectively known as 'Establishment Rules' and are embodied in the Indian Railway 'Establishment Codes' and the Indian Railway 'Establishment Manual'. Permissible deductions can be made from the wages of an employee in the form of Income tax, Employees State Insurance, Provident Fund, and Death-cum-retirement fund. In the words of an officer:

'To increase the productivity of workshops and production units and create incentives for employees and their supervisors, an incentive scheme (Performance Related Pay -PRP) has been in existence in the Railways for many years (initially introduced in 
Chittaranjan Locomotives). Time is the yardstick for measuring work and productivity. 'Allowed time' is fixed after a detailed time study and includes allowances for fatigue, general handling, etc. The scheme enables a workman of average ability to earn 33-1/3\% over and above his basic wage' (Interview- Officer, Central Railway).

Interestingly, the Ministry of Railways had recently initiated a move to automate all in-house operational and personnel practices, eliminating the age-old manual and paper-based system of maintaining employee records. It proposes to automate the entire Indian Railways system, with a centralised Enterprise Resource Planning (ERP) system. Some of the recommendations of this proposal are to automate/computerise: Annual Confidential Report (Performance Appraisal Report); Leave Management; House Building Advance loans; Provident Fund Advances; Pay Bill Processes; Promotion Processes; Training Management; PC / Car / Scooter Advances; Recruitment; Transfers; Grievances; Penalties; Retirement Management; Staff Benefit Fund; Court Cases; Holiday Homes.

The ministry proposes to make this system user-friendly and deploy it in three languages, English, Hindi and the respective regional language of the state, for example, Marathi in Maharashtra. This will bring about integration of data at a national level. However, there is some resistance from employees to this system, due to fear of job losses and security. Currently, each division or headquarters may have its own in-built internal Personnel Management system. Thus, there is no link between systems - they exist as islands. Western Railway HQ currently has two internal Human Resource Information Systems (HRIS) namely:

1. Personnel Management Information System (PMIS), which covers all employee-related information such as Cadre Strength, Promotion, Posting, Rosters and Leave Records. 2. PRIME system, which is used for Payroll, Settlement and Income Tax-related information. 
A Western Railway officer stated that “... in Bilaspur division of the South Eastern zone, the PMIS System has been integrated with PRIME”. It was also widely felt by officers that an overall ERP implementation impact will be seen within the next 5-8 years. Western Railway has been chosen by the Ministry of Railways for pilot implementation of ERP. The Railway Board plans to commence operations of the ERP system by planting computer Kiosks at various stations and terminals across India. This work has already commenced with creation of employee-related service kiosks in various divisions. These kiosks allow the employees to easily access their service-related information instead of approaching the personnel department.

Over the years, Indian railways have reduced the staff on payroll by $10 \%$, from about 1.58 million in 1999 to about 1.41 million in 2006 . This resulted in the decline of overall expenditure by at least $\$ 431.22$ million in 2006 .

\section{Employment Relations}

Employment relations in the Indian railways have been successfully managed for decades. Since it is such a large organisation, good employment/industrial relations (ER) are vital for Indian Railways. Employees are represented by recognized Trade Unions in the zones, divisions and internal manufacturing PSUs (as part of the overall Indian Railways). ER was generally seen to be congenial among the three main actors: staff, management and trade unions. According to one officer:

'There have been no major industrial conflicts since the historic 1974 strike, which attracted worldwide attention. India has about 150 labour laws, and hence, a large body of labour legislation has been enacted over a period of time to safeguard the interests of industrial and other employees, which are generally applicable to railway workers unless otherwise specified by any law' (Interview- Officer, South-Western Railway). 
A large body of labour legislation has been enacted over a period of time to safeguard the interests of industrial and other employees. These laws are generally applicable to railway workers unless otherwise specified by any law. From an Employment Relations point of view, the following are important: The Industrial Disputes Act, 1947; The Workmen's Compensation Act, 1923; The Minimum Wages Act, 1948; and The Factories Act, 1948. Redressing staff grievances is a very important aspect of employment and human relationship with workers - aligned with a HPWS. According to an officer:

'Indian Railways has institutionalised arrangements for this purpose. Implementation cells ensure that the 'grievance-redressal' machinery functions effectively. Moreover, it is also ensured that all 'commitments and agreements' with the staff are implemented fairly' (Interview, Officer, Central Railway).

\section{Employee welfare-oriented practices}

Staff care and welfare was seen to be the best in the country. In the words of an officer:

'Perhaps no private or public sector company's employees can boast of the welfare and fringe benefits Indian Railways employees enjoy' (Interview- Officer, Central Railway).

As evidence to the above assertion, welfare measures include a whole range of fringe benefits such as:

1. Subsidised housing (46\% staff provided with housing- 2010)

2. Medical care (As of 2010, 121 hospitals; 586 polyclinics; 92 dispensaries)

3. Provision of schooling facilities at many places (although normally education is a State subject) and grant of educational assistance for the children of railway servants (as of 2010, 365 schools; 130,000 students; 5,500 teachers; 1,100 support staff)

4. Provision of railway institutes and clubs for the recreation of railway staff 
5. Establishing holiday homes in suitable places where cheap accommodation is available for all railway staff

6. Promotion of sports and scouting activities, etc.

7. Canteens (as of 2010, 253 in number)

8. Vocational training centres for unskilled and semi-skilled railway workmen and vocational training for children of railway employees.

9. Handicrafts centres have also been established where family members of railway employees learn sewing, knitting etc., and also earn extra income.

10. Three free annual train trips and four at a third of the rate for an employee and his dependent family (class as per position and years of employment)

11. Allocation of $\$ 4$ billion over a five-year period for improvement in safety standards governing track, bridges, and signalling.

There were other welfare facilities that are also unique to Indian Railways. As one officer pointed out:

'Each Railway zone maintains a Staff Benefit Fund. The Fund is administered by a Committee consisting, among others, of railway staff nominated by the recognised union(s)' (Interview- Officer, South-Central Railway).

The objects of the fund are Education of staff and their children; recreation and amusement for staff and their children $(\sim 1 / 8$ th of the amount is spent on promotion of sports; relief of distress, among staff and their families; schemes for sickness or maternity leave of the families of employees (when not covered by the Medical Attendance and Treatment Rules); any other object with the approval of the General Manager.

This is another unique facility in Indian Railways that consists of two categories: (a) Consumer Co-operative Societies (b) Co-operative Credit Societies. In the words of an officer: 
'Consumer Co-operative Societies are those that engage in retail trade to meet the needs of their members. Membership is open to all serving railway employees, who may purchase at least one share of a specified minimum value. The Co-operative Credit Societies/Banks have been set up to encourage the 'habit of thrift' among members. Its aim is to help railway employee's effect savings in their current consumption to meet their future credit needs' (Interview- Officer, Western Railway). As of 2010 the following were functional: 178 registered Railwaymen's Consumer Cooperative Societies; 18 Railwaymen's Co-operative Housing Societies, and 18 Labour Contract Co-operative Societies.

\section{Performance Indicators}

Our second research question was "What are the main financial and non-financial indicators used in defining performance in the Indian Railways?". Qualitative data from the interviews allowed us to understand that the IR managers are concerned with multiple indicators of performance, which is related to the fact that they are a public sector organisation:

'The Indian railways are a highly unionised workforce, with extreme and ongoing interference by political and senior management in the day-to-day workings. As you are aware, a number of unions in India are politically aligned to major political parties, and hence continue to exercise significant forms of direct and indirect influence. On the other hand, there are so many stakeholders that are also effected...our customers, employees, the broad society etc., so it becomes difficult to quantify our performance, as we are responsible to the Railway ministry, to customers, to employees etc. However, we are still a commercial forprofit public sector and have frameworks and parameters on which our performances are judged, and these are not only financial, as you can imagine' (Interview- Officer, Western Railway). 
Additionally, we relied on information from the Indian Railway’s Annual Statistical Statement (2010-11). As described in table 1, we were able to identify both financial (total gross expenditure, cost of staff - directly-hired or hired through contractors -, total cost of staff, percentage of total expenditure spent on staff, and gross earnings) and non-financial (absenteeism due to sickness or labour trouble, diseases, number of train accidents, casualties, and injuries). Table 1 describes the results for each of these performance indicators from 2010-2011, the timeframe when qualitative data were collected. We can see that the total gross expenditure is greatly superior in the Central and South-Central Railways, however the area that has the highest percentage of total expenditure spent on staff is the Western Railway.

The non-financial indicators described in the table were considered extremely relevant in the interviews because they are concerned not only with employees' health and safety, but also public safety. These are crucial for IR's public image and this was strongly emphasized by the managers who were interviewed as exemplified in the previous citation. Among these non-financial indicators, it is particularly relevant to name IR's concerns with absenteeism due to labour trouble (accidents at work), casualties and injuries due to train accidents, and the impact of serious diseases, which can eventually be deadly. These are very significant indicators that are context specific and reflect the very strong impact that IR may have in local communities. 
Table 1. Financial and non-financial performance indicators across six areas of the

Indian Railways in 2010-2011

\begin{tabular}{|c|c|c|c|c|c|c|}
\hline 8 & $\begin{array}{l}\text { Western } \\
\text { Railway }\end{array}$ & $\begin{array}{l}\text { Central } \\
\text { Railway }\end{array}$ & $\begin{array}{l}\text { North- } \\
\text { Eastern } \\
\text { Railway }\end{array}$ & $\begin{array}{l}\text { North- } \\
\text { Central } \\
\text { Railway }\end{array}$ & $\begin{array}{l}\text { South- } \\
\text { Western } \\
\text { Railway }\end{array}$ & $\begin{array}{l}\text { South- } \\
\text { Central } \\
\text { Railway }\end{array}$ \\
\hline $\begin{array}{l}\text { Financial } \\
\text { Indicators } \\
\text { Total Gross } \\
\text { Expenditure }\end{array}$ & 28288195 & 79706039 & 33885335 & 50230224 & 33673671 & 73320143 \\
\hline $\begin{array}{l}\text { Cost of Staff } \\
\text { Directly-hired }\end{array}$ & 457418 & 606407 & 427129 & 439313 & 363478 & 271793 \\
\hline $\begin{array}{l}\text { Hired through } \\
\text { contractors }\end{array}$ & 972393 & 889960 & 493407 & 502067 & 369943 & 465953 \\
\hline $\begin{array}{l}\text { Total Cost of } \\
\text { Staff }\end{array}$ & 1429811 & 1496367 & 920536 & 941380 & 733421 & 737746 \\
\hline $\begin{array}{l}\text { Percentage of } \\
\text { Total Expenditure } \\
\text { Spent on Staff } \\
\text { Gross Earnings }\end{array}$ & 77327182 & 74599573 & 14768083 & 79638896 & 28665916 & 85290073 \\
\hline $\begin{array}{l}\text { Non-Financial } \\
\text { Indicators } \\
\text { Absenteeism due } \\
\text { to sickness and } \\
\text { labour trouble }^{2}\end{array}$ & 619959 & 931034 & & --- & --- & 995594 \\
\hline Diseases $^{3}$ & 2682 & 2501 & 2371 & 733 & 122 & 2329 \\
\hline $\begin{array}{l}\text { Number of train } \\
\text { accidents } 4\end{array}$ & 0.06 & 0.05 & 0.43 & 0.08 & 0.19 & 0.11 \\
\hline Casualties & 12 & 5 & 18 & 2 & & 16 \\
\hline Injuries & 8 & 3 & & & & 13 \\
\hline
\end{tabular}

${ }^{1}$ In thousands of rupees

${ }^{2}$ Number of days lost due to sickness and labour trouble

${ }^{3}$ Number of attacks and deaths under various kinds of diseases on the railway offices (cholera, plague, small pox, malaria, tuberculosis, enteric fever, diphtheria, influenza, mumps, measles, chicken pox, whooping cough)

${ }^{4}$ Per million train kilometres 
Stakeholders influencing decision making in HPWP Railways)

- Railway Service Commissions (for recruitment and selection, and pay)

- Local Political Parties

- Local Employment Exchange

- Employees organised in Trade Unions

- Co-operative Societies

- Managers

- Society (customers)
Recruitment and Selection

- Learning, Training and Development

- Compensation and Benefits

- Employment Relations

- Employee welfare-oriented practices
Performance Indicators

Financial Indicators:

- Percentage of total gross expenditure spent on staff

- Gross earnings

Non-Financial Indicators:

- Absenteeism due to sickness and labour trouble

- Number of attacks and deaths under various kinds of diseases on the railway offices

- Number of train accidents

- Casualties and injuries

Figure 1. Multiple stakeholders, high performance work practices and different indicators of performance in the Indian Railways

\section{Discussion and Conclusions}

This study focused on the case of Indian Railways, the world's largest public sector commercial employer. Our main aim was to investigate the way HPWP are being implemented in this public sector organisation in an emerging market context, acknowledging the role of different stakeholders in decision making, as well as the different indicators used to measure performance.

Our first research question focused on understanding what where the practices that collectively form unique HPWP/S's in the Indian Railways and who were the main stakeholders influencing them. Data from 62 semi-structured interviews allowed us to identify five main sets of practices: recruitment and selection; learning, training and development; compensation and benefits; employment relations; and employee welfareoriented practices. The analysis of these practices and the role of different stakeholders can be analysed using the universalism ('best practice') versus contingency ('best fit') theoretical 
rationale (e.g. Becker and Gerhart, 1996). More specifically, we analyse if practices in the Indian Railways fully fit into a HPWP framework, a fact that would support the universalistic approach, or show deviation from that framework, which would lend more support to the contingency view. Moreover, it is argued that the unique and distinctive competencies in human resources (identified in the Indian Railways, and influenced by several stakeholders), has led to such resources being valuable and rare and in the process help the Indian Railways gain competitive advantage and be sustainable as an important public sector, the world's largest commercial employer (Helfat and Peteraf, 2003).

Considering recruitment and selection, we were able to understand that these involved different stakeholders at different hierarchical levels in the organization: Selection Board, Railway Service Commissions and the local Employment Exchange. This well-structured recruitment and selection process involving multiple key stakeholders is crucial to the public sector context and represents an alignment with similar practices in other contexts, which supports the universalistic approach. However, we were also able to identify practices that are unique to the context, such as the idea of a compassionate appointment of a dependent child or wife on the death of an employee and the calls from political parties regarding appointments.

Concerning learning, training and development, the Indian Railways implements a set of well-established practices that clearly fit within the concept of a HPWS and are aligned with a universalistic approach. In particular, we were able to verify the existence of an annual training calendar planed at the Board level, the collaboration with centralised training institutes, the existence of two hundred Indian Railways' training centres, and initiatives like 'Train the trainer'. Furthermore, the efficacy of training was assessed through exams and simulation exercises, which is consistent of the existence of a link between training and performance management, thus part of a HPWS. 
The practices of compensation and benefits at the Indian Railways reflect a strong connection with the Government, as would be expected in public sector organizations, given that Pay Commissions are appointed by the Government (Ministry of Railways). The pay system is well structured and is characterized by the existence of scales of pay with annual increments, but it also includes performance-based pay, which is a measure strongly associated with a HPWS. Employee relations are characterised by a strong role of recognized trade unions representing employees, considering a large body of legislation and standardized procedures to redress staff grievances. These structured and legally supported systems are also associated with a HPWS. Furthermore, employee welfare-oriented practices include several fringe benefits, such as subsidized housing, medical care, schooling facilities for children, recreation, holiday homes for employees, sports, canteens, vocational training centres, handicrafts centres and free annual train trips. These welfare-oriented practices are considered some of the best in the Indian context and are clearly aligned with a strategy that aims to boost employee commitment (Walton, 1985; Wood 1999a, 1999b; Wood \& Albanese, 1995), thus leading to improved performance (Huselid, 1995).

As mentioned throughout the text, these HPWPs are implemented by different stakeholders, which is fundamentally related to the Indian Railways' size and relevance as the world's largest commercial public sector undertaking. These stakeholders include the Government (Ministry of Railways); Railway Service Commissions (for recruitment and selection, and pay); Local Political Parties, who play a role during recruitment and selection; the local Employment Exchange; employees organised in trade unions, which are recognised and whose role is very strong; co-operative societies of employees; managers, more traditionally, and society in general (customers).

The influence of all these stakeholders in decision-making regarding HPWPs is also related to the way in which performance in the Indian Railways is measured, as multiple 
entities are affected by such performance. This refers to our second research question, which focused on identifying the main financial and non-financial indicators used in defining performance in the Indian Railways. Financial indicators of performance are clearly relevant as this is a commercial organisation. However, the public sector context, and the dimension and social relevance of the Indian Railways also include important concerns with nonfinancial indicators. In contrast with the universalistic nature of their HPWP, the nonfinancial performance indicators assessed by the Indian Railways are clearly specific to the Indian context and to the sector, as they include measures regarding absenteeism due to labour trouble (accidents at work), casualties and injuries due to train accidents, and the impact of serious diseases, which can eventually be deadly. These are very specific indicators that have a strong impact in local communities.

\section{Conclusions}

The main conclusion of this study is that the set of practices identified in the Indian Railways is consistent with a high performance work system (e.g., Huselid, 1995). The practices identified in this organisation are clearly structured and articulated creating a HPWS that aims to develop employee commitment and ultimately performance. These practices are influenced by the voices of multiple stakeholders, not only including the traditionally involved parties such as managers and employees represented by trade unions, but also different Government stakeholders, political parties and members of society (as customers). The existence of multiple stakeholders in decision-making is also associated with different measures of performance, including financial and non-financial indicators, the latest being strongly context-specific. 


\section{References}

Almond, P. (2011), “The sub-national embeddedness of international HRM”. Human Relations, Vol. 64 No. 4, pp. 531-551.

Appelbaum, E., Bailey, T., Berg, P., and Kalleberg, A. L. (2000), Manufacturing advantage: Why high-performance work systems pay off, Cornell University Press, Ithaca, NY.

Arthur, J. B. (1994), "Effects of human resource systems on manufacturing performance and turnover", Academy of Management Journal, Vol. 37 No. 3, pp. 670-687.

Bae, K.-S., Chuma, H., Kato, T., Kim, D.-B., and Ohashi, I. (2011), "High Performance Work Practices and Employee Voice: A Comparison of Japanese and Korean Workers", Industrial Relations, Vol. 50 No. 1, pp. 1-29.

Becker, B. E., Huselid, M. A., and Pinckus, P. S., \& Spratt, M. (1997). HR as a source of shareholder value: Research and recommendations. Human Resource Management Journal, 31, 39-47.

Becker, B., and Gerhart, B. (1996), The Impact of Human Resource Management on Organizational Performance: Progress and Prospects, The Academy of Management Journal, Vol. 39 No. 4, pp. 779-801.

Boselie, P., Dietz, G., and Boon, C. (2005), Commonalties and contradictions in HRM and performance research, Human Resource Management Journal, Vol. 15 No. 3, pp. 67-94.

Boxall, P. and Purcell, J. (2003), Strategy and Human Resource Management, Palgrave Macmillan, Basingstoke and New York.

Budhwar, P., and Varma, A. (2010), Emerging Patterns of HRM in the New Indian Economic Environment, Human Resource Management, Vol. 49 No. 3, pp. 345-351.

Budhwar, P., Luthar, H. K., and Bhatnagar, J. (2006), “The dynamics of HRM systems in Indian BPO firms", Journal of Labor Research, Vol. 27 No. 3, pp. 339-360.

Chiaburu, D. S. (2006),"Managing organizational change in transition economies", Journal of Organizational Change Management, Vol. 19 No. 6, pp. 738 - 746.

Collins, C. J., and Smith, K. G. (2006), "Knowledge exchange and combination: The role of human resource practices in the performance of high-technology firms", Academy of Management Journal, Vol. 49 No. 3, pp. 544-560.

Decramer, A., Smolders, C., and Vanderstraeten, A. (2013), "Employee performance management culture and system features in higher education: Relationship with employee performance management satisfaction”, International Journal of Human Resource Management, Vol. 24 No. 2, 352-371. 
Glover, L., and Butler, P. (2012), "High-performance work systems, partnership and the working lives of HR professionals", Human Resource Management Journal, Vol. 22 No. 2, pp. 199-215.

Guest, D. (2011), "Human resource management and performance: still searching for some answers", Human Resource Management Journal, Vol. 21 No.1, pp. 3-13.

Helfat, C., and Peteraf, M. (2003), "The dynamic resource-based view: Capability lifecycles", Strategic Management Journal, Vol. 24 No. 10, pp. 997-1010.

Huselid, M. A. (1995), “The impact of human resource management practices on turnover, productivity, and corporate financial performance", Academy of Management Journal, Vol. 38 No.3, pp. 635-672.

Hutchinson, S., Purcell, J., \& Kinnie, N. (2000), "Evolving high commitment management and the experience of the RAC call centre", Human Resource Management Journal, Vol. 10 No. 1 , pp. 63-78.

Kaplan, R.S., and Norton, D.P. (1996), "Using the Balanced Scorecard as a Strategic Management System", Harvard Business Review, Vol. 74 No.1, pp.75-85.

Lawler, E. (1986), High-involvement Management, Jossey-Bass, San Francisco.

Legge, K. (1995), Human Resource Management: Rhetorics and Realities, Macmillan, London.

Lebans, M., and Euske, K. (2006), “A conceptual and operational delineation of performance", Business Performance Measurement. Cambridge University Press.

Lynn, L. H. (2006), “US research on Asian Business: A flawed model”. Asian Business and Management, Vol. 5 No. 1, pp. 37-51.

Paauwe, J. (2004), HRM and performance: Achieving long-term viability, Oxford University Press, Oxford.

Patel, P., Messersmith, J., and Lepak, D. (2013), "Walking the tight-rope: An assessment of the relationship between high performance work systems and organizational ambidexterity”, Academy of Management Journal, Vol. 56 No. 5, pp. 1420-1442.

Pereira, V, (2014), Managing People in the World's Largest Commercial Employer: An Exploratory Study on Indian Railways. International Journal of Indian Culture and Business Management. ISSN print: 1753-0806.

Pereira, V. (2015), “Managing people in the world's largest commercial employer: an exploratory study on Indian Railways", International Journal of Indian Culture and Business Management, Vol. 10 No. 2, pp. 136-156. 
Pereira, V., and Fontinha, R. (2015), “An exploration of the role duality experienced by HR professionals as both implementers and recipients of HR practices: Evidence from the Indian Railways. Human Resource Management. DOI: 10.1002/hrm.21717.

Pereira, V., and Malik, A. (2015). Employment Relations in the Indian Railways- A Strong Tripod? Employment relations in today's India, A Special Issue of the International Journal of Employment Studies. Vol. 23, No. 1: 43-61. ISSN: 1039-6993.

Pereira, V., and Malik, A. (2017, forthcoming). Post-colonial hangover? A case of multiple cross-cultural influences on Indian Railways. Social Identities (Journal of Race, Culture and Identity). ISSN 1350-4630. v.

Pereira, V., and Narayanamurthy, G. (2016). "Indian Railways - World's Largest Commercial Employer's Social Capital Inventory". Emerald Emerging Markets Case Studies. ISSN: 2045-0621.

Perry, J. L., and Porter, L. W. (1982). Factors affecting the context for motivation in public organizations. Academy of Management Review, Vol. 7 No. 1, pp. 89-98.

Pfeffer, J. (1994), Competitive Advantage Through People, Harvard Business School Press, Boston, Mass.

Pfeffer, J. (1995), "Producing Sustainable Competitive Advantage through Effective Management of People”, Academy of Management Executive, Vol. 9 No. 1, pp. 55-69.

Pfeffer, J. (1998), "Seven practices of successful organizations", California Management Review, Vol. 40 No. 2, pp. 96-124.

Pil, F., and Macduffie, J. (1996), "The adoption of high-involvement work practices”, Industrial Relations, Vol. 35 No. 3, pp. 423-455.

Posthuma, R. A., Campion, M. C., Masimova, M., and Campion, M. A. (2013), “A high performance work practices taxonomy: Integrating the literature and directing future research", Journal of Management, Vol. 39 No. 5, pp. 1184-1220.

Purcell, J. (2006), “Best practice and best fit: chimera or cul-de-sac?” Human Resource Management Journal, Vol. 9 No. 3, pp. 26-41.

Rainey, H. (2009), Understanding and managing public organisations, Jossey-Bass, San Francisco, CA.

Sun, L. Y., Aryee, S., and Law, K. S. (2007), "High-performance human resource practices, citizenship behavior, and organizational performance: A relational perspective”, Academy of Management Journal, Vol. 50 No.3, pp. 558-577. 
Tung, R. L. (2006), "North American research agenda and methodologies: Past imperfect, future - limitless possibilities", Asian Business and Management, Vol. 5 No. 1, pp. 23 36.

Walton, R. (1985), "From "control" to "commitment" in the workplace", Harvard Business Review, Vol. 63 No. 2, pp. 77-84.

Wood, S. J. \& Albanese, M. (1995), "Can you speak of high commitment management on the shop floor?", Journal of Management Studies, Vol. 32 No. 2, pp. 215-47.

Wood, S. J. (1999a), "Family-friendly management: testing the various perspectives," National Institute Economic Review, Vol. 168 No.1, pp. 99-116.

Wood, S. J. (1999b), "Getting the measure of the transformed high-performance organization", British Journal of Industrial Relations, Vol. 37 No. 3, pp. 391-418.

Wright, P. M., Gardner, T. M., and Moynihan, L. M. (2003), “The impact of HR practices on the performance of business units", Human Resource Management Journal, Vol. 13 No. 3, pp. 21-36. 
Reply to Reviewer(s)' Comments to Author:

Reviewer: 1

Recommendation: Minor Revision

Comments:

1. Literature review needs to be strengthened. Particularly similar studies done in Indian context. What are the HR practices followed in developed countries? Are these similar with the HR practices in India (IR especially)

The performance measures are as per the interviews but what are the other measures exist in literature? Or Are these measures same in both developed and under developed countries?

Reply- We thank the reviewer for this insightful comment. We have now incorporated the same. The basic premise of our research is thus: The Indian Railways, the world's largest commercial public sector enterprise, has been researched for different aspects relating to business and management, such as its management style, human resource management, culture, employment relations etc., in the recent past. This paper contributes to this body of knowledge by identifying the multiple stakeholders and links high performance work practices (HPWP) to different indicators of performance in the Indian Railways.

2. The various High performance work practices described in Indian railways context can be mapped to the performance parameters which they impact. For example, training impacts which kind of performance parameter?

Reply- Thank you for pointing this out too. We have now incorporated this aspect in the discussion. Please refer to figure 1 in the paper, and the discussion around it.

3. Implications can be clearly brought in the paper. For example, which aspects of HPWP are found to be significant and which are not? What are the suggestions for Indian railways to improve?

Reply- Thank you again. We have done the needful. Please also refer to Figure 1 which firstly identifies the multiple stakeholders, and then links the high performance work practices and different indicators of performance in the Indian Railways.

4. Additional Questions:

$<\mathrm{b}>1$. Originality: $</ \mathrm{b}>$ Does the paper contain new and significant information adequate to justify publication? Yes

Reply- Thank you

5. $<\mathrm{b}>2$. Relationship to Literature: $</ \mathrm{b}>$ Does the paper demonstrate an adequate understanding of the relevant literature in the field and cite an appropriate range of literature sources? Is any significant work ignored? Literature review needs to be strengthened. Particularly similar studies done in Indian context. What are the HR practices followed in developed countries? Are these similar with the HR practices in India (IR especially) 
Reply- We thank the reviewer for this insightful comment. We have now incorporated the same. The basic premise of our research is thus: The Indian Railways, the world's largest commercial public sector enterprise, has been researched for different aspects relating to business and management, such as its management style, human resource management, culture, employment relations etc., in the recent past. This paper contributes to this body of knowledge by identifying the multiple stakeholders and links high performance work practices (HPWP) to different indicators of performance in the Indian Railways.

6. The performance measures are as per the interviews but what are the other measures exist in literature? Or Are these measures same in both developed and under developed countries?

Reply- Pleas see above reply, relevant here.

7. $<\mathrm{b}>3$. Methodology: $</ \mathrm{b}>$ Is the paper's argument built on an appropriate base of theory, concepts, or other ideas? Has the research or equivalent intellectual work on which the paper is based been well designed? Are the methods employed appropriate? Yes.

Reply- Thank you.

8. $<\mathrm{b}>4$. Results: $</ \mathrm{b}>$ Are results presented clearly and analysed appropriately? Do the conclusions adequately tie together the other elements of the paper? The various High performance work practices described in Indian railways context can be mapped to the performance parameters which they impact. For example, training impacts which kind of performance parameter?

Reply- Thank you for pointing this out too. We have now incorporated this aspect in the discussion. Please refer to figure 1 in the paper, and the discussion around it.

9. $<\mathrm{b}>5$. Implications for research, practice and/or society: $</ \mathrm{b}>$ Does the paper identify clearly any implications for research, practice and/or society? Does the paper bridge the gap between theory and practice? How can the research be used in practice (economic and commercial impact), in teaching, to influence public policy, in research (contributing to the body of knowledge)? What is the impact upon society (influencing public attitudes, affecting quality of life)? Are these implications consistent with the findings and conclusions of the paper? Implications can be clearly brought in the paper. For example, which aspects of HPWP are found to be significant and which are not? What are the suggestions for Indian railways to improve?

Reply- Thank you again. We have done the needful. Please also refer to Figure 1 which firstly identifies the multiple stakeholders, and then links the high performance work practices and different indicators of performance in the Indian Railways.

10. $<\mathrm{b}>6$. Quality of Communication: $</ \mathrm{b}>$ Does the paper clearly express its case, measured against the technical language of the field and the expected knowledge of the journal's readership? Has attention been paid to the clarity of expression and readability, such as sentence structure, jargon use, acronyms, etc.: yes

Reply- Thank you. 
Reviewer: 2

Recommendation: Major Revision

Comments:

details given in the attached file

1. Additional Questions:

$<\mathrm{b}>1$. Originality: $</ \mathrm{b}>$ Does the paper contain new and significant information adequate to justify publication? The originality is not found in the chosen context except that High Performance Work Practices are studied in the context of Indian Railways. To me, some more inputs are required to make this work original, else it remains a repetition of the work with hardly any expansion and extension of the frontiers of knowledge.

Reply- We thank the reviewer for this insightful comment. We have now incorporated the same. The basic premise of our research is thus: The Indian Railways, the world's largest commercial public sector enterprise, has been researched for different aspects relating to business and management, such as its management style, human resource management, culture, employment relations etc., in the recent past. This paper contributes to this body of knowledge by identifying the multiple stakeholders and links high performance work practices (HPWP) to different indicators of performance in the Indian Railways.

2. $<\mathrm{b}>2$. Relationship to Literature: $</ \mathrm{b}>$ Does the paper demonstrate an adequate understanding of the relevant literature in the field and cite an appropriate range of literature sources? Is any significant work ignored? The author has to bring more rigour, citing existing work to make is appropriate and justified.

Reply- Thank you again. We have done the needful. Please also refer to Figure 1 which firstly identifies the multiple stakeholders, and then links the high performance work practices and different indicators of performance in the Indian Railways. Please note that this has not been done before and adds to new knowledge.

3. $<\mathrm{b}>3$. Methodology: $</ \mathrm{b}>$ Is the paper's argument built on an appropriate base of theory, concepts, or other ideas? Has the research or equivalent intellectual work on which the paper is based been well designed? Are the methods employed appropriate? The paper does not pass this test. Details are given in my comments for author.

Reply- Please note, that this is the only study of this nature and scale. This empirical study in the Indian Railways and was sponsored by a research grant from the Society for Human Resource Management (SHRM; United States). We conducted the study in six zones that would represent different geographical areas of India, namely Western Railways, Central Railways, North-Eastern Railways, North-Central Railways, South-Western Railways, and South-Central Railways. These regions include 30 of the 67 divisions in Indian Railways. 
Further, this study relied on sources of both primary and secondary data. Primary empirical data were collected by conducting 62 semi-structured interviews with top level HR managers and line managers responsible for HR.

4. $<$ b $>4$. Results: $</$ b $>$ Are results presented clearly and analysed appropriately? Do the conclusions adequately tie together the other elements of the paper? This section needs better focus and may be a change in method.

Reply- A robust content analysis was used to interpret qualitative interview data. Secondary data from the Indian Railway's Annual Statistical Statement (2010-11), produced by the Ministry of Railways - Government of India, was used to investigate objective financial indicators like the cost of staff and gross total expenditure and non-financial indicators like absenteeism due to sickness and labour trouble, the number of attacks and deaths under various kinds of diseases on the Railway Offices, the number of train accidents, casualties and injuries.

5. $<\mathrm{b}>5$. Implications for research, practice and/or society: $</ \mathrm{b}>$ Does the paper identify clearly any implications for research, practice and/or society? Does the paper bridge the gap between theory and practice? How can the research be used in practice (economic and commercial impact), in teaching, to influence public policy, in research (contributing to the body of knowledge)? What is the impact upon society (influencing public attitudes, affecting quality of life)? Are these implications consistent with the findings and conclusions of the paper? In the light of comments given above this is evidently absent.

Reply- Based on a strong theoretical background, we investigate two research questions:

Research question 1: What are the unique HRM practices that collectively as a bundle form unique HPWP/S's in the Indian Railways, how are they implemented, and who are the main stakeholders influencing them?

Research question 2: What are the main financial and non-financial indicators used in defining performance in the Indian Railways?

The basic premise of our research is thus: The Indian Railways, the world's largest commercial public sector enterprise, has been researched for different aspects relating to business and management, such as its management style, human resource management, culture, employment relations etc., in the recent past. This paper contributes to this body of knowledge by identifying the multiple stakeholders and links high performance work practices (HPWP) to different indicators of performance in the Indian Railways.

6. $<\mathrm{b}>6$. Quality of Communication: $</ \mathrm{b}>$ Does the paper clearly express its case, measured against the technical language of the field and the expected knowledge of the journal's readership? Has attention been paid to the clarity of expression and readability, such as sentence structure, jargon use, acronyms, etc.: Communication needs to be improved. A brevity may be brought by employing a technical writer.

Reply- Thank you. We have re-read and strengthened the paper to eliminate the above and improve the paper. 